\title{
COMMUNITY-BASED STUDY ON PREVALENCE AND PATTERN OF SELF-MEDICATION PRACTICES AND ITS ASSOCIATED FACTORS IN S.S LAYOUT, DAVANGERE
}

\author{
NAZISH FATHIMA*, ANITTA MARIAM JACOB, ANJU VARUGHESE, ARPITHA ABRAHAM, ASHA MATHEW \\ Department of Pharmacy Practice, Faculty of Pharmacy, Bapuji Pharmacy College, Davangere, Karnataka, India. \\ Email: naazfathima93@gmail.com
}

Received: 05 December 2020, Revised and Accepted: 27 February 2021

\section{ABSTRACT}

Objectives: Self-medication practice is an element of self-care and it is the use of medication without the prescription of health-care professionals. This community-based prospective observational study was undertaken with the aim to evaluate the prevalence and pattern of self-medication practices and to assess the knowledge, attitude, and belief of the subjects toward this practice.

Methods: This study was carried out in S.S Layout, Davangere, for a period of 6 months. The data were collected in predesigned validated questionnaire. A total of 400 subjects were participated in the study.

Results: Among 400 individuals, 280 subjects were practicing self-medication, and this practices were high among females 174 (62\%) than males $106(38 \%)$. The majority of subjects participated in this study were students (36\%). The most common indications for self-medication practice were headache (30\%) followed by fever (25\%) and heartburn (13\%). The highly used drug in this practice was acetaminophen (57\%). The most commonly used category of drugs for self-medication were analgesics (57\%) followed by antacids (17\%) and others (anti-hypertensive, anti-diarrheal, antipyretic, anti-histamines, and laxative) (13\%). The main reasons for self-medication practice were no need to visit the doctor for minor illness (62\%), long distance to health center (24\%), and inability to pay for health-care cost (6\%).

Conclusion: This study shows that self-medication is widely practiced among students in our society. There is dire need to make them aware about the pros and cons of self-medication in order to ensure safe usage of drugs. Interventions are required to reduce the frequency of misuse of drugs.

Keywords: Self-medication practice, Self-care, Self-reliance.

(C) 2021 The Authors. Published by Innovare Academic Sciences Pvt Ltd. This is an open access article under the CC BY license (http://creativecommons.org/ licenses/by/4.0/) DOI: http://dx.doi.org/10.22159/ajpcr.2021v14i4.40454. Journal homepage: https://innovareacademics.in/journals/index.php/ajpcr

\section{INTRODUCTION}

Self-medication practice is an element of self-care and it is the use of medication without the prescription of health-care professionals [1]. It includes purchasing medicines by resubmitting the old prescription, buying medicines without valid prescription, and sharing the medicines with family and friends [2]. There is an importance in communication between patients and health-care providers, otherwise patients will take information and they will process it according to their own insight structure based on their previous experiences [3].

Self-medication practice is a major health concern, because it has its own risks and benefits [4]. However, it is inevitable and it is the greatest responsibility of drug regulatory authorities and healthcare professionals about the control of self-medication practice [5]. Drug resistance pathogens are highly associated with self-medication practice, especially antibiotics, they are habit forming medicines and they are easily available without prescription and this practice jointly with poor information results in undesirable effects [6,7].

Self-medicines practice is inescapable at certain situations, so it should be inspired to the public to exercise responsible self-medication [8]. Major threats of this practice are harmful interactions, delay in seeking appropriate medical advice, inappropriate medical choice and delayed right medical consultation, risk of dependence, and habituation. If it is practiced in a responsible way, it will save the wastage of medical resources and built confidence in their own knowledge $[5,8,9]$.

The pharmacies will act as a sole source for the support and education for the patients with respect to their choice of medication, mostly for the acute illness. Sometimes, they under exploit this support and practice it accordingly to the interpretation in their own consecutive framework and other source of information that improves the rate of this practice are advertisements in magazines, newspapers, and certain other pharmaceutical publications. Several elements have an effect on this practice which includes knowledge about the drugs, gender, personnel orientations, and remunerations [3].

Regulating the support provided by the pharmacy professionals and boosting the awareness for the communities on the side effects is in a great need [1]. It has been practiced largely, because it can save scanty medical resources from being misused on minor conditions, reduce the burden on health-care facilities, and decrease the cost and time that people spend to visit health-care centers for minor symptoms [8].

The objective of this study was to evaluate the prevalence and practice of self-medication practice and to assess the knowledge, attitude, and belief of the subjects toward this practice.

\section{RESULTS}

Among 280 subjects, 147 (52.5\%) participants who aged between 18 and 28 years practiced self-medication as compared to $71(25.4 \%)$ aging between 28 and 38 years followed by 28 (10\%) participants aged between 48 and 58 years old (Table 1 ).

A total of 280 participants practicing self-medication out of which 174 $(62.2 \%)$ were female and the rest 106 (37.8\%) were male (Table 2).

Among 400 subjects, 280 were involved in self-medication, whereas 120 negated the practice of self-medication (Table 3 and Fig. 1). 
Among 280 subjects, 100 (35.8\%) students reported self-medication than the participants working in private sector 51 (18.2\%), government sector 51 (18.2\%), and those who were unemployed $45(16 \%)$ and selfemployed 33 (11.8\%).

Out of 280 subjects, 272 (97.2\%) were having acute illness and $8(2.8 \%)$ were having chronic illness (Table 4).

Most of the subjects, $280(100 \%)$ participated in this study trusted in allopathy (Table 5).

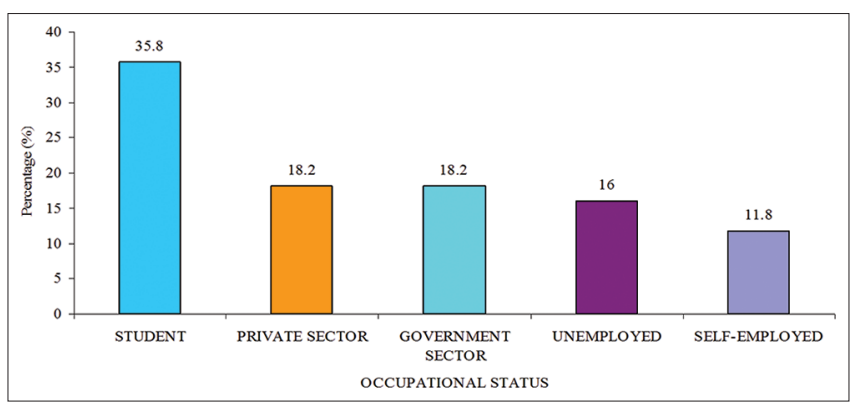

Fig. 1: Graphical representation of occupational status of the subjects undergoing self-medication

Table 1: Distribution of age group based on self-medication practice

\begin{tabular}{lll}
\hline Age (years) & No. of subjects $(\mathbf{n = 2 8 0})$ & Percentage \\
\hline $18-28$ & 147 & 52.5 \\
$28-38$ & 71 & 25.4 \\
$38-48$ & 20 & 7.1 \\
$48-58$ & 28 & 10 \\
$58-68$ & 9 & 3.2 \\
$68-78$ & 5 & 1.8 \\
\hline
\end{tabular}

Table 2: Distribution of gender based on self-medication practice

\begin{tabular}{lll}
\hline Gender & No. of subjects $(\mathbf{n}=\mathbf{2 8 0})$ & Percentage \\
\hline Female & 174 & 62.2 \\
Male & 106 & 37.8 \\
\hline
\end{tabular}

Table 3: Distribution of subjects

\begin{tabular}{lll}
\hline Practice & No. of subjects $(\mathbf{n = 4 0 0 )}$ & Percentage \\
\hline Self-medicated & 280 & 70 \\
Non-self-medicated & 120 & 30 \\
\hline
\end{tabular}

Table 4: Severity of illness

\begin{tabular}{lll}
\hline Types of illness & No. of subjects $(\mathbf{n}=\mathbf{2 8 0})$ & Percentage \\
\hline Acute illness & 272 & 97.2 \\
Chronic illness & 8 & 2.8 \\
\hline
\end{tabular}

Table 5: System of medicine for self-medication

\begin{tabular}{lll}
\hline System of medicines & No. of subjects $(\mathbf{n}=\mathbf{2 8 0})$ & Percentage \\
\hline Allopathy & 280 & 100 \\
Ayurveda & 0 & 0 \\
Homeopathy & 0 & 0 \\
Unani & 0 & 0 \\
\hline
\end{tabular}

The most common indication for self-medication were headache $81(28.9 \%)$ followed by fever 71 (25.4\%) and heartburn $36(12.9 \%)$ (Table 6).

The most commonly used category of drugs for self-medication were analgesics 159 (56.8\%) followed by antacids 46 (16.6\%) and antidiarrheal 34 (12.1\%) (Table 7).

Most commonly used drugs for self-medication was found to be paracetamol 146 (52.2\%) followed by Gelusil 40 (14.3\%) and Benadryl $30(10.8 \%)$ (Tables 8 and 9).

The participants obtained information about self-medication commonly from their own experience $117(41.9 \%)$ followed by from previous doctor's prescription 64 (22.8\%) and self-decision 45 (16\%).

The common reason for self-medication was found to be no need to visit the doctor for minor illness 172 (161.5\%), long distance to health center 67 (23.9\%), and inability to pay for health-care cost 18 (6.4\%) (Table 10).

Two hundred and seventy-five (98.2\%) reported that they were not having any undesired effects by self-medication practice (Table 11).

Table 6: Indications for self-medication

\begin{tabular}{lll}
\hline Indications & $\begin{array}{l}\text { No. of subjects } \\
(\mathbf{n = 2 8 0 )}\end{array}$ & Percentage \\
\hline Headache & 81 & 28.9 \\
Fever & 71 & 25.4 \\
Heartburn & 36 & 12.9 \\
Cough & 23 & 8.2 \\
Diarrhea & 19 & 6.8 \\
Others (constipation, ulcer, & 19 & 6.8 \\
hypertension, diabetes, and cold) & & \\
Indigestion & 17 & 6 \\
Menstrual pain & 14 & 5 \\
\hline
\end{tabular}

Table 7: Categories of drugs used for self-medication

\begin{tabular}{lll}
\hline Categories of drugs & $\begin{array}{l}\text { No. of subjects } \\
(\mathbf{n = 2 8 0 )}\end{array}$ & Percentage \\
\hline Analgesics & 159 & 56.8 \\
Antacids & 46 & 16.6 \\
Others (antihypertensives, & 34 & 12.1 \\
anti-diarrheal, antipyretics, & & \\
antihistamines, and laxative) & & \\
Decongestants & 21 & 7.5 \\
Antispasmodics & 15 & 5.3 \\
Lozenges & 3 & 1 \\
Multivitamins & 2 & 0.7 \\
\hline
\end{tabular}

Table 8: Drugs used for self-medication

\begin{tabular}{lll}
\hline Drugs & No. of subjects $(\mathbf{n = 2 8 0})$ & Percentage \\
\hline Paracetamol & 146 & 52.2 \\
Gelusil & 40 & 14.3 \\
Benadryl & 30 & 10.8 \\
Loperamide & 16 & 5.7 \\
Ibuprofen & 13 & 4.6 \\
Pantoprazole & 9 & 3.2 \\
Meftal & 9 & 3.2 \\
Lactulose & 7 & 2.5 \\
Amlodipine & 6 & 2.1 \\
Ceftriaxone & 1 & 0.35 \\
Rabium-20 & 1 & 0.35 \\
Otrivin & 1 & 0.35 \\
Strepsils & 1 & 0.35 \\
\hline
\end{tabular}


Table 9: Sources of information

\begin{tabular}{lll}
\hline Source of information & $\begin{array}{l}\text { No. of subjects } \\
\text { (n=280) }\end{array}$ & Percentage \\
\hline My own experience & 117 & 41.9 \\
Previous doctor's prescription & 64 & 22.8 \\
Self-decision & 45 & 16 \\
Opinion of family members & 23 & 8.2 \\
Opinion of pharmacists & 18 & 6.5 \\
Internet & 7 & 2.5 \\
Advertisement & 6 & 2.1 \\
\hline
\end{tabular}

Table 10: Reasons for self-medication

\begin{tabular}{lll}
\hline Reasons for non-prescribed & $\begin{array}{l}\text { No. of subjects } \\
(\mathbf{n = 2 8 0 )}\end{array}$ & Percentage \\
\hline $\begin{array}{l}\text { No need to visit the doctor for } \\
\text { the minor illness }\end{array}$ & 172 & 61.5 \\
$\begin{array}{l}\text { Long distance to the health } \\
\text { center }\end{array}$ & 67 & 23.9 \\
$\begin{array}{l}\text { Inability to pay for health-care } \\
\text { cost }\end{array}$ & 18 & 6.4 \\
$\begin{array}{l}\text { Lack of trust in health-care } \\
\text { services } \\
\text { Confidence on your knowledge } \\
\text { about medicines }\end{array}$ & 10 & 4.7 \\
\hline
\end{tabular}

Table 11: Undesired effects due to self-medication

\begin{tabular}{lll}
\hline Undesired outcomes & No. of subjects $(\mathbf{n = 2 8 0})$ & Percentages \\
\hline No undesired outcomes & 275 & 98.2 \\
Reactions & 5 & 1.8 \\
Recurrence of symptoms & 0 & 0 \\
\hline
\end{tabular}

\section{DISCUSSION}

In this study, the overall prevalence for self-medication was found to be $70 \%$. This high prevalence is consistent with studies conducted in various parts of India such as Maharashtra (82\%), Nepal (82\%), and Karnataka $(88 \%)[2,8,10]$, whereas, another study conducted in South India showed a low prevalence of $51.7 \%$ [11]. The different states of selfmedication observed in various studies conducted all over India could be due to the fact that some of these studies have taken into account all type of drugs. The nature of definitions region selected is the factors which have affected the prevalence of self-medication in different studies.

On a global front, a study from Nigeria had shown very high prevalence of self-medication $(81.8 \%$ ) [12]. However, the definition used in this study was ever exposed to the practice of self-medication among undergraduates. Chhabra Rajat et al. reported a prevalence of $86 \%$ selfmedication in the past 2 months in tertiary care hospital in Maharashtra. The prevalence of self-medication in the previous studies conducted in different parts of the world has ranged from $38 \%$ to $98 \%$ [13]. Since the characteristics of the study population and the health-care systems differ from country to country, it becomes difficult to compare the results.

Although the prevalence of self-medication tends to vary across studies, determinants and patterns of drug use are similar across studies. Our study reported a higher percentage of females practicing self-medication than males. Many studies conducted in India and neighboring countries had opined the same $[8,10]$. This could be due to the fact that they have a higher purchasing power, they tend to neglect mild illnesses and avoid loss of wages by spending time in hospitals.

Highest proportion of subjects who practiced self-medication was aged between 18 and 28 years in this study which is similar to a study conducted among premedical and undergraduate students [10]. This might be because most of our study population were students. However, other studies conducted at Nepal [8] where the highest prevalence of self-medication was among respondents aged 20, at Nigeria where the highest prevalence of self-medication was among respondents aged 19-23 [12]. This contrast may be due to different age classifications used across various studies.

This study reports that my own experience and previous doctor's prescription were the common source for practicing self-medication. Similar results were obtained in studies conducted in Nigeria and South India [11,12]. Pal et al. reported that information's from textbooks and teachers were common modes of procuring drugs [14]. Kumar et al. reported that source of drug was medical store [15].

Common reasons cited in this study for using self-medication were no need to visit the hospital for minor illness and long distance. Many other studies report similar reasons for using self-medication. Patrick et al., in their study, conducted in Northwest India reported quick cure of illness, saved their time, and gave them a sense of independence to be a major factor in practicing self-medication [16]. Headache, fever, and heartburn were the most common conditions for which people have used selfmedication in this study. These results were similar to other studies conducted in other countries $[2,11,17,18]$. NSAIDs and medications used for managing chronic disease conditions such as BP and diabetes were common drugs procured by recall method by the respondents in our study. This is alarming since intake of medications for chronic disease conditions is prohibited without physician supervision.

The common class of drugs for self-medication cited in this study was analgesics, antacids, and decongestants. Many other studies report similar class. Mensur Shafie et al., in their studies, conducted in Ethiopia reported analgesics as the most common class of drug for self-medication [19]. Pal et al. reported that antacids, analgesics, and antipyretics were the common class of drug for self-medication [14]. This study reports that acetaminophen is the most common drug used for self-medication. Similar results were obtained in studies conducted in Nigeria, Maharashtra $[10,12]$. Most of the respondents in our study were not having any undesired effects (98.2\%).

\section{CONCLUSION}

The majority of study subjects were students, which suggest that there is a great need in addressing this self-medication practice to the higher authority to implement strict actions. The common indications for selfmedication practice were headache $(30 \%)$ and acetaminophen $(52 \%)$ was the most commonly used drug. Analgesics and antacids are the most commonly used category of drugs. Among them, the main reasons for self-medication practice were no need to visit the doctor for minor illness, long distance to health center, and inability to pay for healthcare cost. Most of the participants were not having any undesired effects. From this study, it has been concluded that self-medication is becoming more common worldwide. Self-medication has both benefits and risks and it is widely prevalent among the adolescence. The health-care pattern adopted during adolescence may carry over into adulthood. Therefore, proper care and awareness should be taken to avoid the further complications. With the perceptions of this study, further community-based researches could be done to explore the unknown facts and prevalence of self-medication in the community.

\section{ACKNOWLEDGMENT}

We are highly grateful to our Principal Dr. A. P. Basavarajappa and Dr. J. Thimmasetty, Head of the Department of Pharmacy Practice for providing us with all the facilities to carry out our study and for the encouragement given to us throughout the project.

\section{AUTHORS' CONTRIBUTIONS}

Anitta Mariam Jacob, Anju Varughese, Arpitha Abraham, and Asha Mathew collected the data, analyzed the results, and wrote the first draft of this paper. The study was done under the guidance of Dr. Nazish Fathima. All authors reviewed and provided comments on subsequent iterations. 


\section{CONFLICTS OF INTEREST}

The author(s) declared that they have no conflicts of interest.

\section{AUTHORS' FUNDING}

The author(s) received no specific funding for this work.

\section{REFERENCES}

1. Kassie AD, Bifftu BB, Mekonnen HS. Self-medication practice and associated factors among adult household members in Meket district, Northeast Ethiopia, 2017. BMC Pharmacol Toxicol 2018;19:15.

2. Gupta S, Singh M. Self-medication among North Indian first-year undergraduate healthcare students: A questionnaire-based study. Trop J Med Res 2016;19:162.

3. Giriraju A. Perception about self-medication practices for oral health problems among the general population of Davangere city, Karnataka, India. J Indian Assoc Public Health Dent 2014;12:219.

4. Patel PM, Prajapati AK, Ganguly B, Gajjar B. Study on impact of pharmacology teaching on knowledge, attitude and practice on selfmedication among medical students. Int J Med Sci Public Health 2013;2:181-6

5. Mehta RK, Sharma S. Knowledge, attitude and practice of selfmedication among medical students. Age (Years) 2015;20:65-3.

6. Amaha MH, Alemu BM, Atomsa GE. Self-medication practice and associated factors among adult community members of Jigjiga Town, Eastern Ethiopia. PLoS One 2019;14:e0218772.

7. Shamsudeen SM, Priya RS, Sujatha G, Muruganandhan J, Manikandan K. Self-medication with antibiotics: A knowledge, attitude, and practice appraisal of 610 dental patients in Chennai, India, from 2016 to 2017. J Educ health Promot 2018;7:66.

8. Gyawali S, Shankar PR, Poudel PP, Saha A. Knowledge, attitude and practice of self-medication among basic science undergraduate medical students in a medical school in Western Nepal. J Clin Diagn Res 2015;9:FC17-22

9. Karmacharya A, Uprety BN, Pathiyil RS, Gyawali S. Knowledge and practice of self-medication among undergraduate medical students. J Lumbini Med Coll 2018;6:21-6.

10. Rajat C, Deshmukh JB, Tamboli SB, Laxmi B, Deshmukh AC. Study of self-medication among medical undergraduate students in a Tertiary Care Hospital, Maharashtra, India. Int J Health Sci Res 2015;5:190-6.

11. Kumar CA, Revannasiddaiah N. Assessment of self-medication patterns in a rural area of south India: A questionnaire based study. J Community Med Public Health 2018;5:354-60.

12. Esan DT, Fasoro AA, Odesanya OE, Esan TO, Ojo EF, Faeji CO. Assessment of self-medication practices and its associated factors among undergraduates of a private University in Nigeria. J Environ Public Health 2018;2018:5439079.

13. Patil SB, Vardhamane SH, Patil BV, Santoshkumar J, Binjawadgi AS, Kanaki AR. Self-medication practice and perceptions among undergraduate medical students: A cross-sectional study. J Clin Diagn Res 2014;8:HC20-3.

14. Pal J, Ahmad S, Pal P, Chatterjee D. Prevalence and pattern of selfmedication among undergraduate students in a medical college of Kolkata. Int J Community Med Public Health 2017;4:3619-24.

15. Sankdia RK, Agrawal M, Rekha PB, Kothari N. A questionnaire based study regarding the knowledge, attitude and practice of self-medication among second year undergraduate medical students. Int J Pharmacol Clin Sci 2017;6:1-5.

16. Patrick S, Badyal D. Self-medication practices in patients attending a tertiary care teaching hospital in Urban North-West India. Acta Med Int 2018;5:44

17. Shehnaz SI, Khan N, Sreedharan J, Issa KJ, Arifulla M. Self-medication and related health complaints among expatriate high school students in the United Arab Emirates. Pharm Pract (Granada) 2013;11:211-8.

18. Tesfamariam S, Anand IS, Kaleab G, Berhane S, Woldai B, Habte E, et al. Self-medication with over the counter drugs, prevalence of risky practice and its associated factors in pharmacy outlets of Asmara, Eritrea. BMC Public Health 2019;19:159

19. Shafie M, Eyasu M, Muzeyin K, Worku Y, Martin-Aragon S. Prevalence and determinants of self-medication practice among selected households in Addis Ababa community. PLoS One 2018;13:e0194122. 